\title{
The adenomatous polyposis coli protein and retinoblastoma protein are cleaved early in apoptosis and are potential substrates for caspases
}

\author{
Sara J. Browne ${ }^{1,4}$, Marion MacFarlane ${ }^{2,4}$, Gerald M. Cohen ${ }^{2,3}$ \\ and Christos Paraskeva ${ }^{1}$ \\ ${ }^{1}$ CRC Colorectal Tumour Biology Research Group, Department of Pathology \\ and Microbiology, University of Bristol, Bristol, UK \\ 2 MRC Toxicology Unit, Hodgkin Building, University of Leicester, Lancaster \\ Road, Leicester LE1 9HN, UK \\ ${ }^{3}$ corresponding author: G.M. Cohen \\ ${ }^{4}$ These authors contributed equally to the work.
}

Received: 10.6.97; revised 8.9.97; accepted; 15.9 .97

Edited by M. Piacentini

\begin{abstract}
Apoptosis in human monocytic THP.1 tumour cells, induced by diverse stimuli, was accompanied by proteolytic cleavage of the adenomatous polyposis coli gene product (APC) and by sequential cleavage of the retinoblastoma susceptibility gene product $(\mathrm{Rb})$. Cleavage of poly(ADPribose) polymerase (PARP), APC and the initial cleavage of $\mathrm{Rb}$ at the carboxy terminal region all occurred at a similar time, early in the apoptotic process. Subsequently, $\mathbf{R b}$ underwent a secondary cleavage to $43 \mathrm{kDa}$ and $30 \mathrm{kDa}$ protein fragments. Two caspase inhibitors, benzyloxycarbonyl-Val-Ala-Asp (OMe) fluoromethyl ketone (Z-VAD.FMK) and acetyl-Tyr-Val-Ala-Asp chloromethyl ketone (YVAD.CMK), had markedly different effects on the induction of apoptosis. Z-VAD.FMK inhibited the primary and secondary cleavage of $R b$, cleavage of APC and PARP, and apoptosis assessed by flow cytometry. In marked contrast, YVAD.CMK inhibited cleavage of APC and the secondary cleavage of $\mathrm{Rb}$ to the $43 \mathrm{kDa}$ and $30 \mathrm{kDa}$ protein fragments but did not inhibit the primary carboxy terminal cleavage of Rb, PARP proteolysis or apoptosis assessed by flow cytometry. These results suggest that different caspases are responsible for the cleavage of different substrates at different stages during the apoptotic process and that a caspase may either cleave APC directly or may be involved in the pathway leading to APC proteolysis. This is the first report suggesting that a cytoplasmic tumour suppressor gene (APC) may be cleaved by a caspase during apoptosis.
\end{abstract}

Keywords: apoptosis; Z-VAD.FMK; YVAD.CMK; APC; Rb

Abbreviations: PARP, poly(ADP-ribose) polymerase; ZVAD.FMK, benzyloxycarbonyl-Val-Ala-Asp (OMe) fluoromethyl ketone; YVAD.CMK, acetyl-Tyr-Val-Ala-Asp chloro- methyl ketone; TLCK, tosyl-L-lysinyl chloromethyl ketone; APC, adenomatous polyposis coli; $\mathrm{Rb}$, retinoblastoma susceptibility gene product

\section{Introduction}

Apoptosis is a physiological form of cell death characterised by cell shrinkage, nuclear condensation and fragmentation (Wyllie et al, 1984; Arends and Wyllie, 1991). Apoptosis is important in normal development and tissue homeostasis and perturbation of the apoptotic process may be important in many human diseases, including cancer (Wyllie et al, 1984; Arends and Wyllie, 1991). In the nematode, Caenorhabditis elegans, 131 cells die during development. The gene, ced-3, is required for these cells to die and it encodes a protein, CED-3, with considerable sequence homology to mammalian interleukin-1 $\beta$-converting enzyme protease (ICE now termed caspase-1) (Yuan et al, 1993; Alnemri et al, 1996). Subsequently, a family of caspases has been identified, all containing an active QACXG ( $\mathrm{X}=\mathrm{R}, \mathrm{G}$ or $\mathrm{Q})$ pentapeptide motif (reviewed by Kumar, 1995; Martin and Green, 1995; Thornberry and Molineaux, 1995; Cohen, 1997). All caspases are synthesized as inactive proenzymes, which are processed proteolytically at aspartic acid (Asp) cleavage sites to generate a large and a small subunit, which form the active enzyme (Thornberry and Molineaux, 1995; Cohen, 1997). Activated caspases also cleave their substrates after Asp residues. Three sub-families of caspases have been identified, the CED-3 subfamily comprising caspase-3 (CPP32/Yama/apopain), caspase-7 (Mch3/ICE-LAP3/CMH1), caspase-6 (Mch2) and caspase-9, the caspase-1 subfamily comprising caspase- 1 , caspase -4 (Tx/ICE rel-II/ Ich2) and caspase-5 (ICE rel-III) and the NEDD-2 subfamily comprising caspase 2 (Ich-1) and its murine homologue, NEDD-2 (Chinnaiyan and Dixit, 1996; Takahashi and Earnshaw, 1996).

During the early stages of apoptosis, several nuclear proteins are degraded including histones, lamins, DNA topoisomerase I and II, poly(ADP-ribose) polymerase (PARP) and U1 small ribonucleoprotein. PARP cleavage has proved to be a useful early marker of apoptosis (Kaufmann, 1989; Kaufmann et al, 1993). In addition, two tumour suppressor gene products have been shown to be cleaved during apoptosis; the retinoblastoma susceptibility gene product $\mathrm{Rb}$ and the adenomatous polyposis coli gene product APC (Browne et al, 1994). The Rb tumour suppressor gene encodes a nuclear phosphoprotein that participates in the transition between $\mathrm{G} 1$ and S-phases of the cell cycle (reviewed in Ewen, 1994). Rb has been proposed to play a role in protecting cells from apoptosis (Haas-Kogan et al, 1995; Haupt et al, 1995), possibly through its interactions with 
E2F as free E2F may induce apoptosis (Qin et al, 1994; Wu and Levine, 1994; Almasan et al, 1995).

APC protein is a cytoplasmic protein, which like $R b$, is constitutively expressed in many tissue types, for example, lung, breast, prostate, pancreas, cervix, lymphoid and colon (Smith et al, 1993). The function of the APC protein is not known but it may play a role in regulating cell-cell adhesion through its binding to $\beta$-catenin (Rubinfeld et al, 1993; Su et al, 1993). APC competes for $\beta$-catenin binding with $\mathrm{E}$ cadherin (Rubinfeld et al, 1993). The binding of $\beta$-catenin to E-cadherin activates cadherin mediated cell-cell adhesion (reviewed in Birchmeier et al, 1995). It is important to note however that E-cadherin is not expressed by all cell types expressing APC, for example lymphoid tissues. Interestingly APC may modulate the expression of $\beta$-catenin (Munemitsu et al, 1995) and has thus been implicated to have a role in signal transduction (reviewed by Kinzler and Vogelstein, 1996). In addition, APC binds to the tubulin cytoskeleton and has therefore been implicated to have a role in the control of cell shape (Munemitsu et al, 1994; Smith et al, 1994). APC also binds to DLG, the human homologue of the Drosophila discs large protein and has been suggested to have a role in neurone functioning (Matsumine et al, 1996). APC protein is cleaved in apoptotic cells (Browne et al, 1994). Although the functional significance of this cleavage is not fully understood, it suggests that APC may have a role in apoptosis (Browne et al, 1994). Consistent with this suggestion, fulllength APC has recently been demonstrated to induce apoptosis in the colorectal tumour cell line HT29, which expresses two truncated APC proteins (Morin et al, 1996).

Apoptosis in the human monocytic cell line THP.1 can be induced with a wide range of stimuli (Zhu et al, 1995). In these cells, the trypsin-like serine protease inhibitor, $\mathrm{N} \alpha$ tosyl-L-lysinyl chloromethyl ketone (TLCK), enhances apoptosis induced by cycloheximide, an inhibitor of protein synthesis or thapsigargin, a microsomal $\mathrm{Ca}^{2+}$-ATPase inhibitor. In contrast, the induction of apoptosis by the DNA topoisomerase II inhibitor, etoposide is inhibited by TLCK (Zhu et al, 1995). Apoptosis induced by DNA damaging agents in HL-60 and U937 cells was also inhibited by TLCK (Gong et al, 1993; An and Dou, 1996), whereas apoptosis in HL-60 cells induced by cycloheximide was potentiated by TLCK (Gong et al, 1993). Previously, we reported cleavage of $\mathrm{APC}$ and Rb proteins during apoptosis in three cell types, however the timing of these events in the apoptotic process has not been studied (Browne et al, 1994). Studying the timing of APC and Rb cleavage is important as it may give a clue to the importance of APC and $\mathrm{Rb}$ in apoptosis (Chen et al, 1997). In the present study apoptosis was induced in THP.1 cells using divergent stimuli and we have investigated the timing of APC and $R b$ cleavage relative to poly(ADP-ribose) polymerase (PARP) proteolysis, an early marker of apoptosis (Kaufmann et al, 1993). We have also utilised the two caspase inhibitors, benzyloxycarbonyl-Val-Ala-Asp (OMe) fluoromethyl ketone (Z-VAD.FMK) and Acetyl-Tyr-Val-Ala-Asp chloromethyl ketone (YVAD.CMK), to investigate whether one or more caspases are involved in the pathways leading to APC and $\mathrm{Rb}$ cleavage in apoptosis.

\section{Results}

\section{APC and Rb proteolysis in THP. 1 cell apoptosis induced by diverse stimuli}

Apoptosis was induced in THP.1 cells by incubation for up to $4 \mathrm{~h}$ with cycloheximide/TLCK $(25 \mu \mathrm{M} / 100 \mu \mathrm{M})$ or thapsigargin/TLCK $(100 \mathrm{nM} / 100 \mu \mathrm{M})$ or by incubation for up to $6 \mathrm{~h}$ with etoposide $(25 \mu \mathrm{M})$ as previously described (Zhu et al, 1995). Protein samples were prepared from control and treated cells and the expression of APC and Rb proteins examined. APC protein expression was measured using the amino-terminal antibody FE9 (Smith et al, 1993) and Rb protein expression was detected using the Rb245 antibody. In apoptotic colonic epithelial cells, APC is cleaved to a $90 \mathrm{kDa}$ protein fragment and $\mathrm{Rb}$ is cleaved to $43 \mathrm{kDa}$ and $30 \mathrm{kDa}$ protein fragments (Browne et al, 1994). Following exposure of THP.1 cells for $4 \mathrm{~h}$ to apoptotic stimuli, the $90 \mathrm{kDa}$ cleavage product of APC protein (Figure 1) and the $43 \mathrm{kDa}$ and $30 \mathrm{kDa}$ cleavage products of the $\mathrm{Rb}$ protein (Figure 2 ) were also detected.

The timing of APC and Rb cleavage was determined relative to PARP cleavage and apoptosis. Cycloheximide/ TLCK, thapsigargin/TLCK and etoposide all induced apoptosis in THP.1 cells (Table 1) and this occurred in a time dependent manner. Protein samples were prepared after 1, 2 and $4 \mathrm{~h}$ treatment with cycloheximide/TLCK and thapsigargin/TLCK, and after 2, 4 and $6 \mathrm{~h}$ treatment with etoposide as etoposide-induced apoptosis was delayed compared to the other stimuli. In untreated control cells almost all the PARP and APC were present as intact

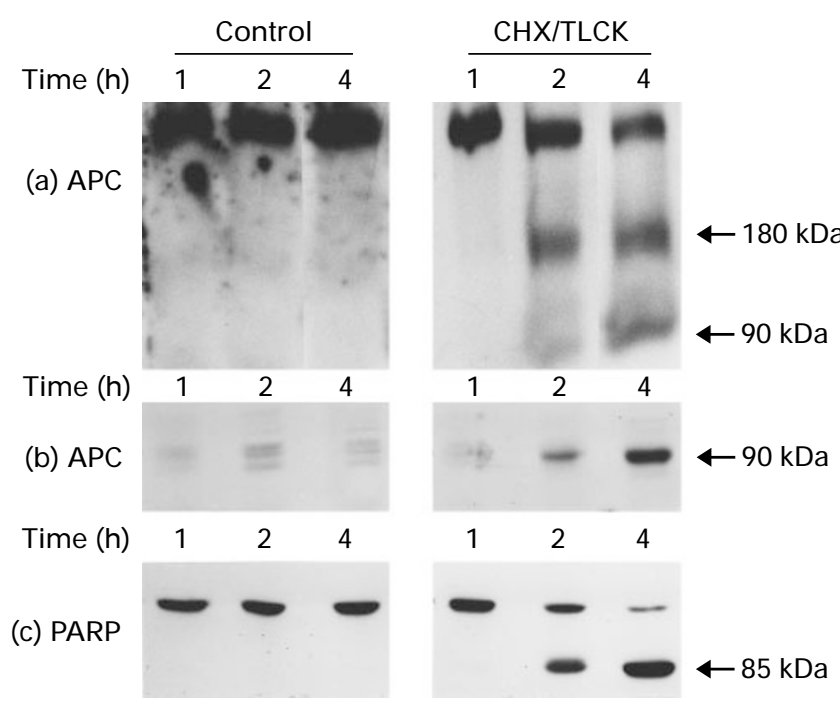

Figure $1 \mathrm{APC}$ and PARP cleavage during cycloheximide/TLCK-induced apoptosis. THP. 1 cells were treated for 1,2 and $4 \mathrm{~h}$ with cycloheximide $(25 \mu \mathrm{M})$ and TLCK $(100 \mu \mathrm{M})$. Protein samples were prepared at these times and separated on either 3\% agarose or 10\% acrylamide gels to detect APC proteolysis (a and $\mathbf{b}$ respectively) or $7.5 \%$ acrylamide gel to detect PARP proteolysis (c). APC protein was detected using the amino terminal antiody FE9 and PARP protein was detected using the PARP antibody kindly provided by Dr. G Poirier. The $180 \mathrm{kDa}$ and $90 \mathrm{kDa}$ cleavage products of APC and the $85 \mathrm{kDa}$ cleavage product of PARP are indicated. Although the $300 \mathrm{kDa}$ intact APC protein was not transferred from the acrylamide gels, the $90 \mathrm{kDa}$ cleaved fragment was more clearly observed 


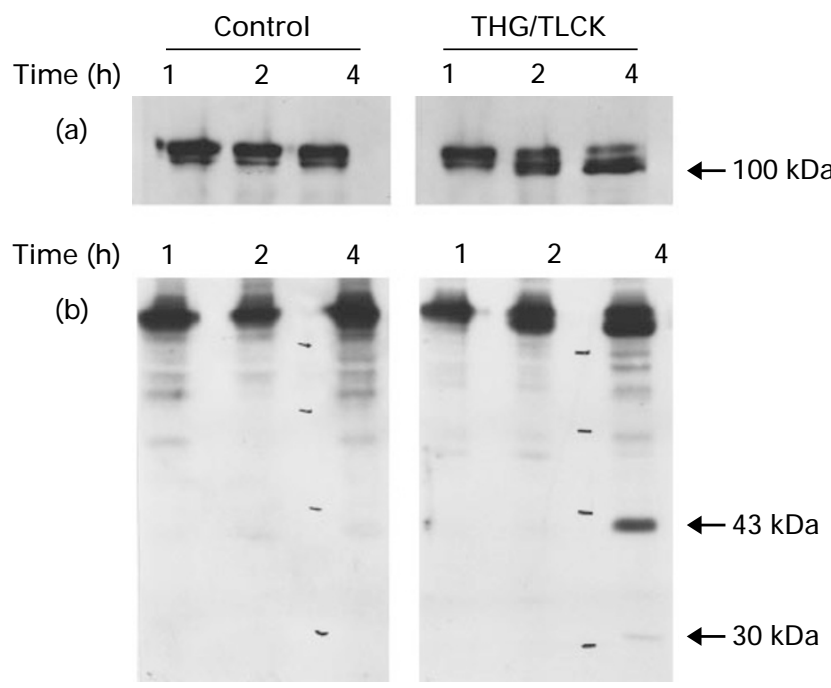

Figure 2 Rb cleavage during thapsigargin/TLCK-induced apoptosis. THP.1 cells were incubated for up to $4 \mathrm{~h}$ either alone or in the presence of thapsigargin (THG) $(100 \mathrm{nM})$ and TLCK $(100 \mu \mathrm{M})$. Protein samples were prepared at the indicated times and separated on a $6.5 \%$ and $10 \%$ acrylamide gel to detect (a) Rb primary carboxy terminal cleavage and (b) Rb secondary cleavage respectively. $\mathrm{Rb}$ protein was detected using the $\mathrm{Rb} 245$ antibody. The carboxy terminal cleaved product, $43 \mathrm{kDa}$ and $30 \mathrm{kDa}$ cleaved products of $\mathrm{Rb}$ are indicated

proteins with little or no cleavage products being detected (Figure 1). After $2 \mathrm{~h}$ treatment with cycloheximide/TLCK, proteolysis of intact PARP $(116 \mathrm{kDa})$ to its signature $85 \mathrm{kDa}$ fragment was detected above control levels, whereas after $4 \mathrm{~h}$ treatment most but not all of the PARP was cleaved to this size of fragment (Figure 1c). Similarly, after 2 and $4 \mathrm{~h}$ treatment with cycloheximide/TLCK, loss of intact APC protein was accompanied by appearance of a $90 \mathrm{kDa}$ APC cleavage product (Figure 1a and b). Interestingly in this cell line, in addition to the $90 \mathrm{kDa}$ protein, a further band at approximately $180 \mathrm{kDa}$ was detected in apoptotic cells (Figure 1a). This $180 \mathrm{kDa}$ protein was not detected in three other apoptosis systems when APC was cleaved to a $90 \mathrm{kDa}$ protein fragment (Browne et al, 1994) and may represent another cleavage product of the APC protein. These data suggested that the APC protein cleavage product accumulated at a similar time to the PARP cleavage product. The results shown for cycloheximide/TLCK were representative of the results found with either thapsigargin/TLCK or etoposide. Proteolysis of PARP and APC was detected above control levels after $2 \mathrm{~h}$ treatment with thapsigargin/TLCK and $4 \mathrm{~h}$ treatment with etoposide (data not shown). The timing of APC and PARP proteolysis was coincident with the detection of morphological apoptosis assessed by flow cytometry $(\mathrm{H}$. Zhu - personal communication).

$\mathrm{Rb}$ protein cleavage has been previously shown to occur in apoptotic cells (Browne et al, 1994; An and Dou, 1996). Using the Rb245 antibody to detect Rb proteolysis, $\mathrm{Rb}$ protein was cleaved to $43 \mathrm{kDa}$ and $30 \mathrm{kDa}$ products in THP. 1 cells exposed for $4 \mathrm{~h}$ to thapsigargin/TLCK (Figure $2 b)$. Similarly, cleavage of $\mathrm{Rb}$ was observed after $4 \mathrm{~h}$
Table 1 Inhibition of apoptosis by Z-VAD.FMK but not YVAD.CMK

\begin{tabular}{|c|c|c|c|}
\hline \multirow[b]{2}{*}{ Treatment } & \multicolumn{3}{|c|}{$\%$ Apoptosis } \\
\hline & - & Z-VAD.FMK & YVAD.CMK \\
\hline Control & $1.90 \pm 0.54(4)$ & $4.8 \pm 1.30(4)$ & $1.9(2)$ \\
\hline $\begin{array}{l}\text { Cycloheximide/ } \\
\text { TLCK }\end{array}$ & $48.2 \pm 6.9(4)$ & $3.3 \pm 2.5(3)$ & $46.3(2)$ \\
\hline $\begin{array}{l}\text { Thapsigargin/ } \\
\text { TLCK }\end{array}$ & $33.3 \pm 7.4(4)$ & $3.0 \pm 2.0$ & $22.1(2)$ \\
\hline Etoposide & $39.7(2)$ & $2.1(2)$ & $36.5(2)$ \\
\hline
\end{tabular}

THP.1 cells were incubated for $1 \mathrm{~h}$ alone or in the presence of Z-VAD.FMK $(50 \mu \mathrm{M})$ or YVAD.CMK $(100 \mu \mathrm{M})$. They were then further incubated for $4 \mathrm{~h}$ in the presence of cycloheximide $(25 \mu \mathrm{M})$ together with TLCK $(100 \mu \mathrm{M})$ or thapsigargin $(100 \mathrm{nM})$ together with TLCK $(100 \mu \mathrm{M})$. In the case of etoposide, cells were incubated for $6 \mathrm{~h}$ in order to induce a higher level of apoptosis. The percentage of apoptotic cells was assessed by flow cytometry as described in Materials and Methods. Results are expressed as the mean \pm S.E. and the number of experiments indicated in brackets

treatment with cycloheximide/TLCK or $6 \mathrm{~h}$ treatment with etoposide (Figures 4 and 5). Thus with all three apoptosisinducing stimuli, cleavage of $\mathrm{Rb}$ to the $43 \mathrm{kDa}$ and $30 \mathrm{kDa}$ protein fragments occurred later than either PARP or APC proteolysis. Recently, $\mathrm{Rb}$ has also been shown to be cleaved early in apoptosis with loss of the carboxy terminal 42 amino acids (Janicke et al, 1996; Chen et al, 1997; Tan et al, 1997). Interestingly, a shift to a lower molecular weight form of $\mathrm{Rb}$ was detected after $2 \mathrm{~h}$ treatment with thapsigargin/TLCK (Figure $2 \mathrm{a}$ ) or cycloheximide/TLCK and after $4 \mathrm{~h}$ with etoposide (data not shown). To determine whether the lower molecular weight form of $\mathrm{Rb}$ was due to either a change in phosphorylation state (An and Dou, 1996), or due to the carboxy terminal cleavage of $\mathrm{Rb}$ (Janicke et al, 1996; Chen et al, 1997; Tan et al, 1997), samples were separated on a $6.5 \%$ acrylamide gel, probed with the $\mathrm{Rb}$ antibody $\mathrm{Rb} 245$ and reprobed with the carboxy terminal $\mathrm{Rb}$ antibody $\mathrm{C}-15$. If the lower molecular weight form of $\mathrm{Rb}$ was due to an alteration in phosphorylation state, then the lower molecular weight protein should be detectable with both antibodies. However, if it was due to cleavage of the carboxy terminal region of $\mathrm{Rb}$, then the protein would only be detected with the Rb245 antibody. When separated on a $6.5 \%$ acrylamide gel, an immunoreactive band was detected with a lower molecular weight than hypophosphorylated $\mathrm{Rb}$ (Figure 2a). As this was only detected with the Rb245 antibody, it suggested that the protein fragment was due to cleavage of the carboxy terminal region of $\mathrm{Rb}$. This primary cleavage of $\mathrm{Rb}$ was observed after $2 \mathrm{~h}$ treatment with the apoptotic stimuli prior to the secondary cleavage of $\mathrm{Rb}$ to the $43 \mathrm{kDa}$ and $30 \mathrm{kDa}$ protein products (Figure 2 and data not shown).

As treatment of THP.1 cells for $4 \mathrm{~h}$ with cycloheximide/ TLCK did not result in $100 \%$ apoptosis (Table 1), a mixed population of cells with normal or apoptotic morphology was present. Some full-length APC (data not shown) and intact PARP protein was always detected at the $4 \mathrm{~h}$ time point as well as their cleavage products (Figure 1). In order to determine whether the remaining full-length protein was due to non-apoptotic cells in the mixed cell population, cells 
(a) APC 1

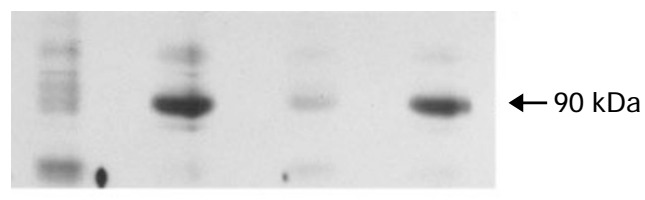

(b) $\mathrm{Rb}$

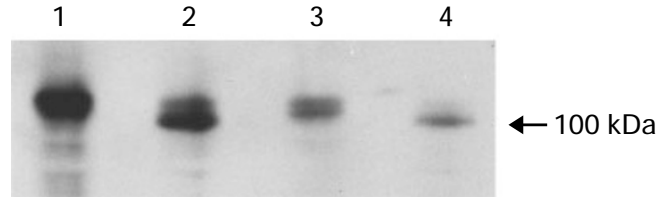

Figure 3 APC and Rb proteolysis in pure populations of normal and apoptotic cells. THP.1 cells were treated for $3 \mathrm{~h}$ either alone (lane 1) or with cycloheximide $(25 \mu \mathrm{M})$ and TLCK $(100 \mu \mathrm{M})$ (lane 2). The treated cells were then stained with Hoechst 33342 and sorted by flow cytometry into cells with low blue fluorescence which exhibited a normal morphology (lane 3 ), and cells with a high blue fluorescence, which displayed an apoptotic morphology (lane 4). These cells were separated on a $10 \%$ and $6.5 \%$ acrylamide gel to detect (a) APC proteolysis and (b) Rb primary cleavage respectively. APC protein expression was analyzed using the antibody FE9 and Rb proteolysis was detected using the antibody Rb245. The $90 \mathrm{kDa}$ APC cleavage product and the carboxy terminal cleaved $\mathrm{Rb}$ fragment are indicated

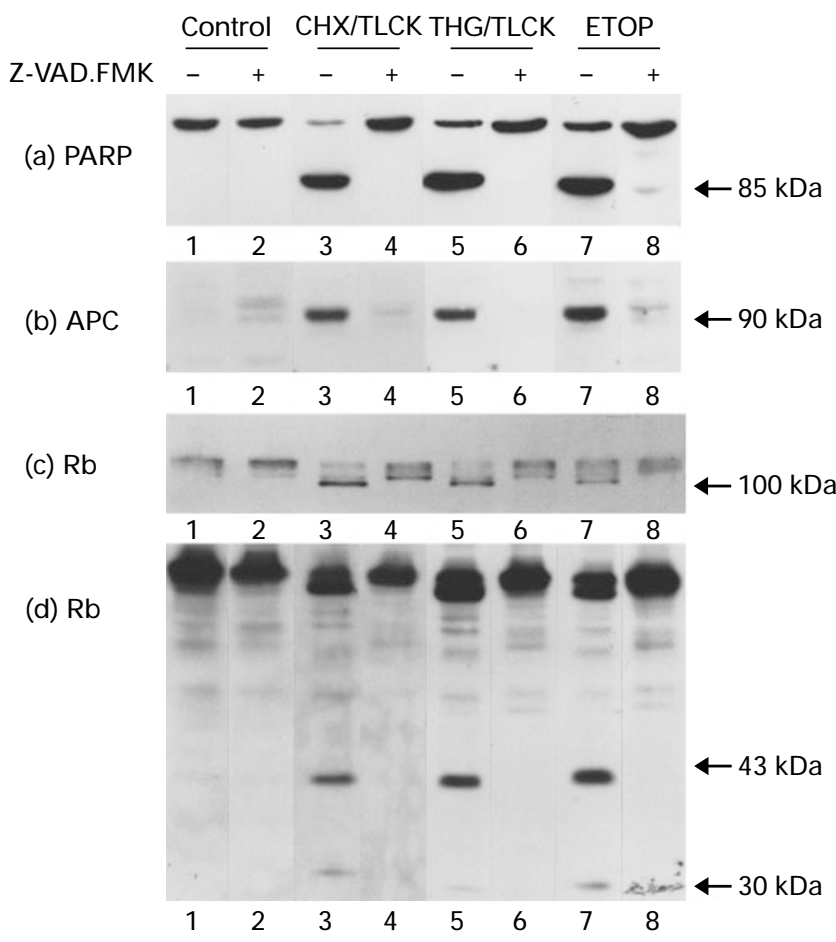

Figure 4 Z-VAD.FMK inhibits PARP and APC proteolysis, and the primary and secondary cleavage of Rb. THP.1 cells were incubated for $6 \mathrm{~h}$ alone (lane 1). Cells were also incubated for $4 \mathrm{~h}$ with either cycloheximide $(\mathrm{CHX}) / \mathrm{TLCK}$ (lane 3), thapsigargin (THG)/TLCK (lane 5), or for $6 \mathrm{~h}$ with etoposide (ETOP) (lane 7). Cells were preincubated for $1 \mathrm{~h}$ with Z-VAD.FMK $(50 \mu \mathrm{M})$ followed by an incubation either alone for $6 \mathrm{~h}$ (lane 2), with cycloheximide/TLCK for $4 \mathrm{~h}$ (lane 4), with thapsigargin/TLCK for $4 \mathrm{~h}$ (lane 6 ) or with etoposide for $6 \mathrm{~h}$ (lane 8). The proteolysis of (a) PARP and (b) APC, and the (c) primary and (d) secondary cleavage of $\mathrm{Rb}$ was investigated. The $90 \mathrm{kDa}$ APC fragment, $85 \mathrm{kDa}$ PARP fragment, carboxy terminal cleaved $\mathrm{Rb}$ fragment, and the $43 \mathrm{kDa}$ and $30 \mathrm{kDa} \mathrm{Rb}$ fragments are indicated. Equal loading of samples was checked by Ponceau S staining of the PVDF membrane (data not shown)

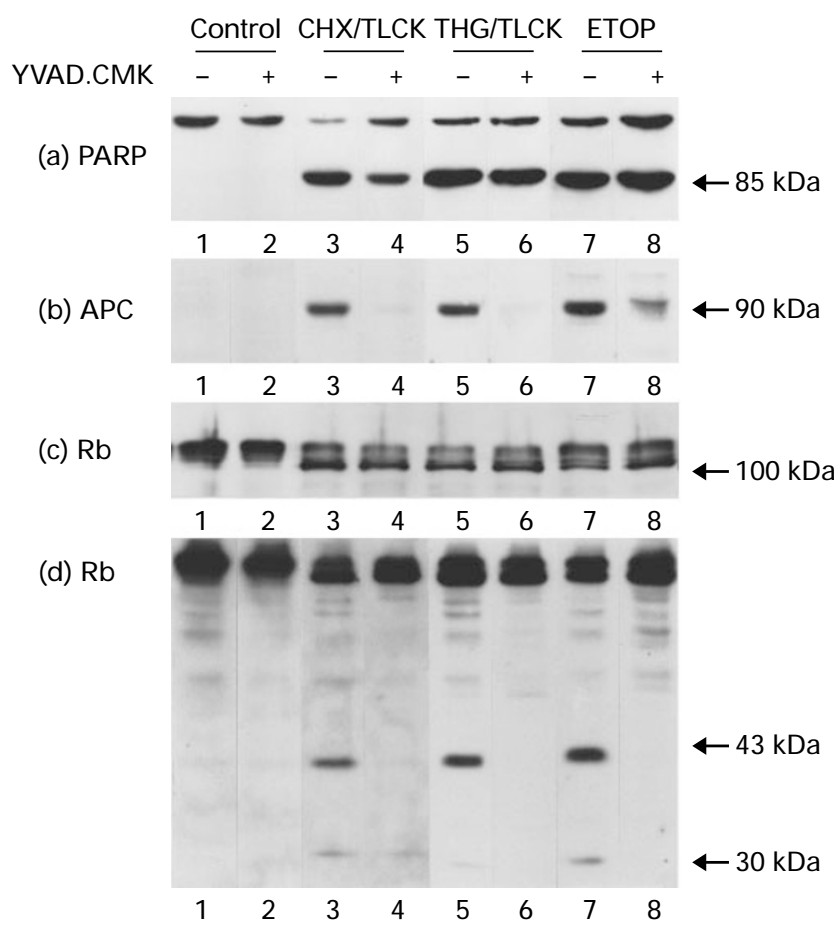

Figure 5 YVAD.CMK inhibits APC proteolysis and Rb secondary cleavage, but not PARP proteolysis or Rb primary cleavage. THP.1 cells were incubated in an identical manner to that described in the lengend to Figure 4 except that cells in lanes 2, 4, 6 and 8 were preincubated for $1 \mathrm{~h}$ with YVAD.CMK $(100 \mu \mathrm{M})$ prior to exposure to the apoptotic stimuli

were sorted using a flow cytometer into morphologically normal (low blue fluorescence) and morphologically apoptotic (high blue fluorescence) cell fractions as described in the methods. THP.1 cells were treated with cycloheximide/TLCK for $3 \mathrm{~h}$, which resulted in approximately $40 \%$ apoptotic cells, and then sorted into normal and apoptotic cells. In morphologically normal cells, PARP was detected predominantly as the full-length $116 \mathrm{kDa}$ protein, whereas in apoptotic cells it was present as the cleaved $85 \mathrm{kDa}$ PARP fragment (MacFarlane et al, 1997). In the unsorted cells, APC protein was cleaved to a $90 \mathrm{kDa}$ fragment and the carboxy terminus of $\mathrm{Rb}$ was also cleaved compared to control cells (compare Figure $3 a$ and b, lanes 1 and 2). In the morphologically normal sorted cells, fulllength APC was detected (data not shown) with only a small amount of the $90 \mathrm{kDa}$ fragment (Figure 3a, lane 3) and $\mathrm{Rb}$ was predominantly in the hyperphosphorylated form with no detectable carboxy terminal cleaved $\mathrm{Rb}$ (Figure $3 \mathrm{~b}$ lane 3). In contrast, in the apoptotic cells the $90 \mathrm{kDa}$ protein fragment (Figure $3 a$ lane 4) and the carboxy terminal cleaved form of $\mathrm{Rb}$ (Figure $3 b$, lane 4) were the predominant immunoreactive species detected. Thus the detection of both intact and cleaved APC and PARP in the $4 \mathrm{~h}$ samples after induction of apoptosis was consistent with the fact that not all the cells were apoptotic. Furthermore, the cleavage of APC to the $90 \mathrm{kDa}$ fragment and the carboxy terminal cleavage of $\mathrm{Rb}$ occurred primarily in the apoptotic cells. 


\section{Z-VAD.FMK inhibits proteolysis of PARP, APC and Rb}

Having shown that APC and Rb proteins were cleaved in THP. 1 cells during apoptosis, the possible role of caspases in this cleavage was investigated using the caspase inhibitor $Z$ VAD.FMK. Z-VAD.FMK inhibits apoptosis in THP.1 cells as measured by flow cytometry, PARP proteolysis, formation of large kilobase fragments of DNA and internucleosomal cleavage of DNA (Zhu et al, 1995). Pretreatment of THP.1 cells with Z-VAD.FMK $(50 \mu \mathrm{M})$ for $1 \mathrm{~h}$ completely inhibited apoptosis induced by diverse stimuli (Table 1). Treatment of THP. 1 cells for $4 \mathrm{~h}$ with cycloheximide/TLCK, or thapsigargin/ TLCK, or for $6 \mathrm{~h}$ with etoposide resulted in extensive cleavage of PARP to its characteristic $85 \mathrm{kDa}$ fragment (Figure $4 \mathrm{a}$ lanes 3,5 and 7) compared to control cells (Figure 4a lanes 1 and 2). This cleavage of PARP was almost totally inhibited by Z-VAD.FMK (Figure 4a lanes 4, 6 and 8). Similarly all three apoptotic stimuli resulted in extensive cleavage of APC protein to a $90 \mathrm{kDa}$ fragment (Figure $4 \mathrm{~b}$ lanes 3, 5 and 7), cleavage of the carboxy terminal region of $\mathrm{Rb}$ (Figure $4 \mathrm{c}$ lanes 3, 5 and 7) and $\mathrm{Rb}$ proteolysis to the $43 \mathrm{kDa}$ and $30 \mathrm{kDa}$ fragments (Figure $4 d$ lanes 3,5 and 7 ). All of these cleavages were almost totally inhibited by Z-VAD.FMK (Figure $4 b-d$ lanes 4, 6 and 8 ) suggesting that $\mathrm{Rb}$ and $\mathrm{APC}$ proteins may be proteolytically cleaved by a caspase(s). Z-VAD.FMK blocked all the parameters of apoptosis measured in this study and further supported our previous suggestion that Z-VAD.FMK blocks apoptosis at an early stage in the apoptotic program (Zhu et al, 1995; MacFarlane et al, 1997).

\section{YVAD.CMK inhibits APC and Rb secondary cleavage but not PARP proteolysis or Rb primary cleavage}

In order to gain further insight into the nature of the caspase(s) responsible for the cleavage of $\mathrm{APC}$ and $\mathrm{Rb}$, we also used the caspase inhibitor YVAD.CMK. YVAD.CHO was designed initially to reversibly inhibit caspase-1 with a $\mathrm{Ki}$ in the nanomolar range (Thornberry et al, 1992). Using the same tetrapeptide motif, YVAD.CMK was synthesized as an irreversible inhibitor of caspase-1 but it also inhibits other caspases including the proteolytic activity described as prICE (Lazebnik et al, 1994). Prior to exposure to different apoptotic stimuli, THP. 1 cells were pretreated for $1 \mathrm{~h}$ with YVAD.CMK $(100 \mu \mathrm{M})$, a concentration which inhibits Rb proteolysis in $\mathrm{HL}-$ 60 cells and U937 cells (An and Dou, 1996). YVAD.CMK did not inhibit apoptosis as assessed by flow cytometry (Table 1) but it partially inhibited internucleosomal cleavage of DNA (data not shown) in agreement with previous results (Zhu et al, 1995). All three apoptotic stimuli again induced extensive cleavage of PARP to an $85 \mathrm{kDa}$ fragment (Figure 5a lanes 3, 5 and 7). However, YVAD.CMK $(100 \mu \mathrm{M})$ caused a slight but clearly incomplete inhibition of the proteolysis of PARP induced by the three apoptotic stimuli (Figure 5a lanes 4, 6 and 8 ). In marked contrast, APC cleavage induced by all three apoptotic stimuli was almost totally inhibited by YVAD.CMK (Figure 5b compare lanes 3, 5 and 7 with 4, 6 and 8). Lower concentrations of YVAD.CMK $(5-50 \mu \mathrm{M})$ were also shown to inhibit cleavage of APC (data not shown). This data demonstrated that the protease that cleaved APC was much more sensitive to inhibition by YVAD.CMK than the protease that cleaved PARP. Interestingly, the primary carboxy terminal cleavage of $\mathrm{Rb}$ induced by all three apoptotic stimuli (Figure $5 c$ lanes 3, 5 and 7) was not inhibited by YVAD.CMK (Figure 5c lanes 4, 6 and 8 ) whereas secondary cleavage to $43 \mathrm{kDa}$ and $30 \mathrm{kDa}$ protein fragments was inhibited (Figure $5 \mathrm{~d}$ compare lanes 3, 5 and 7 with 4, 6 and 8). These results suggested that different caspases may be responsible for the primary and secondary cleavage of $\mathrm{Rb}$.

\section{Discussion}

\section{APC proteolysis in apoptosis}

The human monocytic THP.1 cell line expressed full-length APC protein, which was cleaved to a $90 \mathrm{kDa}$ protein fragment during apoptosis induced by diverse stimuli (Figures 1, 4 and $5)$, consistent with the similar cleavage of APC in spontaneous apoptosis in colonic epithelial cell lines and in a SV40 transformed fibroblast cell line, and in calcium ionophore-induced apoptosis in a Burkitt lymphoma cell line (Browne et al, 1994). Although we have previously demonstrated cleavage of APC protein during apoptosis, when this proteolysis occurred relative to morphological and biochemical markers of apoptosis was unclear. Also the type of protease involved in APC cleavage was not known. In this study, cleavage of APC protein occurred at a similar time to proteolysis of PARP which has been proposed to be an early event in apoptosis (Kaufmann et al, 1993). In addition, we have shown that the two different caspase inhibitors, ZVAD.FMK and YVAD.CMK, had markedly different effects on the cleavage of APC and PARP. Z-VAD.FMK, as well as inhibiting PARP proteolysis (Zhu et al, 1995; MacFarlane et al, 1997), also inhibited APC proteolysis (Figure 4). In contrast, YVAD.CMK $(100 \mu \mathrm{M})$ inhibited APC but not PARP cleavage (Figure 5). That both Z-VAD.FMK and YVAD.CMK inhibited APC cleavage suggests that a caspase may cleave APC or may be involved in the pathway leading to APC cleavage. In addition, the data suggests that APC protein may be cleaved by a different caspase(s) from that responsible for the cleavage of PARP. However, we cannot totally exclude the possibility that APC and PARP were cleaved by the same caspase but cleavage of PARP by this enzyme was much less susceptible to inhibition by YVAD.CMK.

Although the precise cleavage site(s) of APC are not known, potential caspase cleavage sites exist near the region of APC postulated to be cleaved during apoptosis. Proteolysis of PARP in intact cells is primarily carried out by caspase-3 (CPP32) and/or caspase-7 (Mch3) (Fernandes-Alnemri et al, 1995a; Nicholson et al, 1995; Tewari et al, 1995), although other caspases including recombinant caspase-1 (ICE), caspase-4 (TX) and caspase-6 (Mch2) when used at high concentrations can also cleave PARP (Fernandes-Alnemri et al, 1995b; Gu et al, 1995). In some model systems, the lamin protease is two orders of magnitude more sensitive to inhibition by YVAD.CMK than the PARP protease (Lazebnik et al, 1995). Caspase-6 (Mch2) but not caspase-3 or caspase-7 is capable of cleaving lamins (Orth et al, 1996; Takahashi et al, 1996). In 
THP.1 cells undergoing apoptosis, cleavage of lamins is accompanied by the activation/processing of caspase- 6 and YVAD.CMK inhibited the cleavage of the lamins but not the loss of intact caspase- 6 suggesting that it inhibited the activity of caspase- 6 but not its processing (MacFarlane et al, 1997). The susceptibility of cleavage of APC to inhibition by YVAD.CMK suggests that caspase- 6 may be a possible candidate although the involvement of other caspases cannot be excluded. Further studies with purified caspases are necessary to clearly identify the enzyme(s) which cleaves APC.

The functional significance of APC cleavage in apoptosis is currently not known. Most of the known functional domains of APC are lost in proteolysis to the $90 \mathrm{kDa}$ protein, including the catenin binding site, the region involved in modulation of $\beta$-catenin expression, and the EB1, DLG and cytoskeleton binding domains. Interestingly, APC has been demonstrated to bind tubulin and affect the construction of the tubulin cytoskeleton (Munemitsu et al, 1994; Smith et al, 1994). Cleavage of APC during apoptosis may therefore regulate some of the cytoplasmic changes that occur during apoptosis. Although the significance of APC proteolysis is unclear, we have previously suggested that APC may have a role in apoptosis/cell survival (Browne et al, 1994). APC protein is expressed in many normal cell types and its expression has been shown to increase in differentiated cells (Smith et al, 1993). In particular, in the colonic crypt APC protein expression has been shown to increase as the cells migrate towards the top of the crypt (Smith et al, 1993). It was suggested that the increased APC expression may result in apoptosis in the migrating cells as recent studies have shown that expression of wild-type APC induced apoptosis in a colorectal tumour cell line expressing two mutant APC proteins (Morin et al, 1996). Clearly it would be of interest to determine whether APC has a role in the induction of apoptosis in normal cells as well as in tumour cells. The expression of wild-type APC in colorectal carcinoma cells could result in apoptosis as a result of conflicting signals brought about by the introduction of a wild-type tumour suppressor gene.

Although APC has been shown to be cleaved during apoptosis, APC proteolysis is not necessary for apoptosis to occur. This is because YVAD.CMK was shown to inhibit APC proteolysis but did not inhibit morphological apoptosis. Z-VAD.FMK inhibits apoptosis at an early stage in the apoptosis programme (MacFarlane et al, 1997). This may possibly be after the cells are committed to die but prior to the morphological and biochemical measurements of apoptosis (McCarthy et al, 1997). YVAD.CMK inhibits only some features of the apoptotic phenotype, such as cleavage of lamins (Lazebnik et al, 1995; MacFarlane et al, 1997) and cleavage of APC and Rb possibly because its most susceptible targets are only activated at a later stage of the apoptotic programme. YVAD.CMK also inhibits internucleosomal cleavage of DNA (Zhu et al, 1995). Thus APC cleavage and DNA laddering may result from activation of a similar caspase(s). Further work is necessary in order to determine the significance of APC in apoptosis.

\section{Rb proteolysis in apoptosis}

In this study, we have demonstrated that $\mathrm{Rb}$ protein is cleaved twice during apoptosis in THP.1 cells. Initially, it is cleaved early in the apoptotic process at a similar time to PARP and APC proteolysis. The size of the $\mathrm{Rb}$ cleavage product is consistent with the carboxy-terminal cleavage of $\mathrm{Rb}$ at the DEAD $\downarrow G$ site reported by Janicke et al (1996), Chen et al (1997) and Tan et al (1997). The secondary cleavage of $R b$ occurred later than PARP and APC proteolysis, coinciding with the detection of internucleosomal DNA cleavage. During the secondary cleavage, $\mathrm{Rb}$ protein was cleaved to $43 \mathrm{kDa}$ and $30 \mathrm{kDA}$ protein products, consistent with results found in three other apoptosis systems (Browne et al, 1994). This is the first report demonstrating that the primary and secondary cleavage of $\mathrm{Rb}$ occur with different timing in apoptosis. The functional significance of the primary and secondary cleavage of $\mathrm{Rb}$ protein in apoptosis is not known. Interestingly, it has been demonstrated that the carboxy-terminal cleaved form of $\mathrm{Rb}$ was no longer able to bind Mdm-2, however it was still able to bind E2F (Janicke et al, 1996; Chen et al, 1997). This may suggest that loss of Mdm-2 binding by $R b$ is an important event in apoptosis. Alternatively, retention of E2F binding by $\mathrm{Rb}$ may be important early in apoptosis. In support of this suggestion, Chen et al (1997) demonstrated that carboxy terminal cleavage of $\mathrm{Rb}$ enhanced E2F binding to $\mathrm{Rb}$. The selective inactivation of $R b$ functions may have a role in ordering the timing of events in the apoptosis process.

The two caspase inhibitors had different effects on the primary and secondary cleavage of Rb. Z-VAD.FMK completely inhibited cleavage of Rb, however, YVAD.CMK inhibited the secondary cleavage but not the primary carboxy-terminal cleavage. This is the first report of a caspase inhibitor blocking secondary but not primary cleavage of $\mathrm{Rb}$. Caspase-3 and/or caspase- 7 have been proposed to cleave the carboxy terminal fragment of $R b$ based partly on the presence of the DEAD $\downarrow$ G sequence at the $\mathrm{Rb}$ cleavage site (Janicke et al, 1996; Chen et al, 1997; Tan et al, 1997), similar to the DEVD $\downarrow$ G sequence which is cleaved in PARP (Lazebnik et al, 1994), and compatible with the presence of a DXXD motif commonly found in most caspase-3 and caspase-7 substrates (Cohen, 1997). Our findings that YVAD.CMK did not inhibit PARP cleavage or $\mathrm{Rb}$ carboxy terminal cleavage (Figure 5 ) further supports the suggestion that the initial cleavage of $\mathrm{Rb}$ is mediated by caspase-3 and/or caspase-7. The identity of the caspase responsible for the secondary cleavage of $\mathrm{Rb}$ is not known. The different inhibitor profiles may suggest a different caspase was responsible for the primary and secondary cleavage. The susceptibility of this secondary cleavage to YVAD.CMK again suggested that caspase- 6 may be involved. However, the different time course of the appearance of the $90 \mathrm{kDa}$ fragment of $\mathrm{APC}$ and $43 \mathrm{kDa}$ and $30 \mathrm{kDa}$ fragments of $\mathrm{Rb}$ also suggested that different caspases may be involved in these cleavages. Thus our data provide indirect evidence for the involvement of at least three caspases in the cleavage of APC and $R b$. Firstly, caspase-3 and/or caspase-7, which is responsible for the C-terminal cleavage of $\mathrm{Rb}$ as well as for PARP proteolysis, secondly an unidentified caspase which is 
responsible for the early cleavage of APC to a $90 \mathrm{kDa}$ fragment and thirdly a caspase responsible for the later cleavage or $\mathrm{Rb}$ to $43 \mathrm{kDa}$ and $30 \mathrm{kDa}$ fragments. Both the latter caspases are susceptible to inhibition by YVAD.CMK but are activated at different times in the apoptotic process. Again, we cannot exclude that these cleavages may be mediated by the same caspase which has different affinities to different substrates depending on factors, such as accessibility. Further studies using purified caspases will be necessary to clearly identify which proteases are responsible for the primary and secondary cleavage of $\mathrm{Rb}$.

To summarise, we have demonstrated that APC protein was cleaved at a similar time to PARP proteolysis. $\mathrm{Rb}$ protein was sequentially cleaved during apoptosis with the initial cleavage occurring at a similar time to that of PARP cleavage, while the secondary cleavage occurred approximately $2 \mathrm{~h}$ later. Z-VAD.FMK inhibited all the morphological and biochemical features of apoptosis measured, including PARP, APC and Rb protelysis whereas YVAD.CMK inhibited APC proteolysis and the secondary cleavage of $\mathrm{Rb}$ but not PARP proteolysis, the primary cleavage of $\mathrm{Rb}$ or morphological apoptosis as assessed by flow cytometry. The data presented suggests for the first time that a caspase may cleave APC protein or may be involved in the pathway leading to APC proteolysis. Our original observation that APC was cleaved in apoptosis and the recent observation that APC induces apoptosis (Morin et al, 1996) indicates that APC may have an important role in apoptosis. Further work will be necessary to determine the significance of APC in apoptosis.

\section{Materials and Methods}

\section{Materials}

All medium and serum used were purchased from Gibco (Paisley, UK). TLCK was obtained from Boehringer Mannheim UK (Lewes, UK), the caspase inhibitors Z-VAD.FMK and YVAD.CMK were obtained from Enzyme Systems Inc. (Dublin, CA, USA) and Bachem (Bubendorf, Switzerland) respectively. The purified mouse monoclonal antibody to APC, FE9 was purchased from Oncogene Science, Inc (Cambridge, MA, USA), purified mouse monoclonal to $\mathrm{Rb}, \mathrm{Rb} 245$ was obtained from PharMingen (Cambridge, UK), rabbit polyclonal antibody to the carboxy terminus of $\mathrm{Rb}, \mathrm{C}-15$ was obtained from Santa Cruz Biotechnology, Inc (California) and the antibody to PARP (rabbit antiserum 318) was a kind gift from Dr. G Poirier (Laval University, Quebec, Canada).

\section{Cell culture}

The human monocytic cell line THP.1 was obtained from Dr. K Whaley, University of Leicester and grown as described previously (Zhu et al, 1995). Apoptosis was induced in THP.1 cells by incubation for up to $4 \mathrm{~h}$ with cycloheximide/TLCK $(25 \mu \mathrm{M} / 100 \mu \mathrm{M})$ or thapsigargin/TLCK $(100 \mathrm{nM} / 100 \mu \mathrm{M})$ or by incubation for up to $6 \mathrm{~h}$ with etoposide $(25 \mu \mathrm{M})$. In experiments with caspase inhibitors, cells were preincubated for $1 \mathrm{~h}$ with Z-VAD.FMK $(50 \mu \mathrm{M})$ or YVAD.CMK $(100 \mu \mathrm{M})$ in order to facilitate their entry into cells. Z-VAD.FMK was supplied with the Asp in the P1 position being esterified in order to increase cell permeability.

\section{Apoptosis assessed by flow cytometry}

The method for the detection, separation and quantitation of morphologically normal and apoptotic THP.1 cells has been previously described (Zhu et al, 1995). Cells were stained with Hoechst 33342 $(1.5 \mu \mathrm{g} / \mathrm{ml})$ and propidium iodide $(0.05 \mu \mathrm{g} / \mathrm{ml})$ and analyzed using a Becton Dickinson FACS Vantage flow cytometer (Zhu et al, 1995). Nonviable cells, as indicated by propidium iodide inclusion, were gated out (mean $3.2 \% \pm 0.6$ ). Viable cells were displayed as a cytogram of blue fluorescence versus forward light scatter. The cells exhibiting low blue fluorescence appeared morphologically normal under fluorescence microscopy whereas the high blue cells displayed a typical apoptotic morphology (Zhu et al, 1995). The increased Hoechst staining reflects a change in membrane permeability (Ormerod et al, 1993). Cells were also sorted into two populations, one which exhibited low blue fluorescence and was morphologically normal and the other which exhibited high blue fluorescence and was morphologically apoptotic (MacFarlane et al, 1997).

\section{Protein sample preparation from whole cells}

THP. 1 cells $\left(10^{6}\right)$ were centrifuged at 13000 r.p.m., for $3 \mathrm{~min}$ and washed in PBS. The cells were then resuspended in $50 \mu \mathrm{l}$ of gel sample buffer $(63 \mathrm{mM}$ Tris. $\mathrm{HCl}, \mathrm{pH} 6.8,10 \%$ glycerol, $5 \% 2-$ mercaptoethanol, $2 \%$ SDS and $0.025 \%$ bromophenol blue), boiled for $5 \mathrm{~min}$ and stored at $-20^{\circ} \mathrm{C}$.

\section{SDS-PAGE Western blotting}

Proteins were resolved by SDS-PAGE, transferred onto PVDF membrane (Millipore, Watford, UK) and probed with monoclonal antibodies as described previously (Browne et al, 1994). 10\% Acrylamide gels were used to look for the cleavage products of APC and $\mathrm{Rb}$ proteins, however $7.5 \%$ acrylamide gels were used to investigate PARP cleavage (Kaufmann et al, 1993). In addition, 6.5\% acrylamide gels were used to distinguish between the hyperphosphorylated and carboxy terminal cleaved forms of $\mathrm{Rb}$ (Janicke et al, 1996).

\section{Agarose Western blotting}

Full-length APC protein has a molecular weight of $300 \mathrm{kDa}$ and is difficult to transfer using standard SDS-PAGE Western blotting techniques. Samples were therefore run on $3 \%$ agarose gels using the previously described method (Smith et al, 1993). Although this method detects both intact and cleaved APC products, the acrylamide blots were better for detecting the $90 \mathrm{kDa}$ cleaved product and were therefore used in most of the experiments.

\section{Acknowledgements}

This work was funded by the Medical Research Council and a programme grant from the British Cancer Research Campaign. We thank Dr. G Poirier for the PARP antibody. We thank Roger Snowden for help with the flow cytometry.

\section{References}

Almasan A, Yin Y, Kelly RE, Lee EY-HP, Bradley A, Li W, Bertino JR and Wahl GM (1995) Deficiency of retinoblastoma protein leads to inappropriate S-phase entry, activation of E2F-responsive genes, and apoptosis. Proc. Natl. Acad. Sci. USA. $92: 5436-5440$ 
Alnemri ES, Livingston DJ, Nicholson DW, Salvesen G, Thornberry NA, Wong WW and Yuan JY (1996) Human ICE/CED-3 protease nomenclature. Cell 87: 171

An B and Dou QP (1996) Cleavage of retinoblastoma protein during apoptosis: interleukin-1 $\beta$-converting enzyme-like protease as candidate. Cancer Res. 56: $438-442$

Arends MJ and Wyllie AH (1991) Apoptosis - mechanisms and roles in pathology. Int Rev. Exp. Pathol. 32: 223-254

Birchmeier W, Hulsken J and Behrens J (1995) Adherens junction proteins in tumour progression. Cancer Surveys: Cell Adhesion and Cancer 24: 129-140

Browne SJ, Williams AC, Hague A, Butt AJ and Paraskeva C (1994) Loss of APC protein expressed by human colonic epithelial cells and the appearance of a specific low-molecular-weight form is associated with apoptosis in vitro. Int. J. Cancer. 59: 56-64

Chen W-D, Otterson GA, Lipkowitz S, Khleif SN, Coxon AB and Faye FJ (1997) Apoptosis is associated with cleavage of a $5 \mathrm{kDa}$ fragment from $\mathrm{RB}$ which mimics dephosphorylation and modulates E2F binding. Oncogene 14: 1243-1248

Chinnaiyan AM and Dixit VM (1996) The cell-death machine. Curr. Biol. 6: 555-562

Cohen GM (1997) Caspases: the executioners of apoptosis. Biochem J. 326: 1-16

Ewen ME (1994) The cell cycle and the retinoblastoma protein family. Cancer and Metastasis Rev. 13: 45-66

Fernandes-AlnemriT, Littwack Gand AlnemriES (1995b) Mch2, a new member of the apoptotic Ced-3/ICE cysteine protease gene family. Cancer Res. 55: 2737 2742

Fernandes-Alnemri T, Takahashi A, Armstrong R, Krebs J, Fritz L, Tomaselli KJ, Wang L, Yu Z, Croce CM, Salveson G, Earnshaw WC, Litwack G and Alnemri ES (1995a) Mch3, a novel apoptotic cysteine protease highly related to CPP32. Cancer Res. 55: 6045-6052

Gong J, Li X and Darzynkiewics Z (1993) Different patterns of apoptosis of HL60 cells induced by cycloheximide and camptothecin. J. Cell. Physiol. 157: 263-270

Gu Y, Sarnecki C, Aldape RA, Livingston DJ and Su MS-S (1995) Cleavage of poly(ADP-ribose) polymerase by interluekin- $1 \beta$ converting-enzyme and its homologs TX and Nedd-2. J. Biol. Chem. 270: 18715-18718

Haas-Kogan DA, Kogan SC, Levi D, Dazin P, T'Ang A, Fung Y-KT and Israel MA (1995) Inhibition of apoptosis by the retinoblastoma gene product. EMBO J. 14 $461-472$

Haupt Y, Rowan S and Oren M (1995) p53-mediated apoptosis in Hela cells can be overcome by excess pRB. Oncogene 10: 1563-1571

Jänicke RU, Walker PA, Lin XY and Porter AG (1996) Specific cleavage of the retinoblastoma protein by an ICE-like protease in apoptosis. EMBOJ. 15:69696978

Kaufmann SH (1989) Induction of endonucleolytic DNA cleavage in human acute myelogenous leukemia cells by etoposide, camptothecin, and other cytotoxic anticancer drugs: a cautionary note. Cancer Res. 49: 5870-5878

Kaufmann SH, Desnoyers S, Ottaviano Y, Davidson NE and Poirier GG (1993) Specific proteolytic cleavage of poly(ADP-ribose) polymerase: an early marker of chemotherapy-induced apoptosis. Cancer Res. 53: 3976-3985

Kinzler KW and Vogelstein B (1996) Lessons from hereditary colorectal cancer. Cell 87: $159-170$

Kumar S (1995) ICE-like proteases in apoptosis. Trends Biochem. Sci. 20: 198-202

Lazebnik YA, Kaufmann SH, Desnoyers S, Poirier GG and Earnshaw WC (1994) Cleavage of poly(ADP-ribose) polymerase by a proteinase with properties like ICE. Nature 371: $346-347$

Lazebnik YA, Takahashi A, Moir RD, Goldman RD, Poirier GG, Kaufmann SH and Earnshaw WC (1995) Studies of the lamin proteinase reveal multiple paralle biochemical pathways during apoptotic execution. Proc. Natl. Acad. Sci. USA 92: $9042-9046$

MacFarlane M, Cain K, Sun X-M, Alnemri ES and Cohen GM (1997) Processing/ activation of at least four interleukin-1- $\beta$-converting enzyme-like proteases occurs during the execution phase of apoptosis in human monocytic tumour cells. J. Cell Biol. 137: 469-479

Martin SJ and Green DR (1995) Protease activation during apoptosis: death by a thousand cuts? Cell $82: 349-352$

Matsumine A, Akiko O, Senda T, Okumura N, Satohm K, Baeg G-H, Kawahara T, Kobayashi S, Okada M, Toyoshima K and Akiyama T (1996) Binding of APC to the human homolog of the Drosophila Discs Large tumor suppressor protein. Science 272: $1020-1023$

McCarthy NJ, Whyte MKB, Gilbert CS and Evan GI (1997) Inhibition of ced-3/ICErelated proteases does not prevent cell death induced by oncogenes, DNA damage, or the bcl-2 homologue Bak. J. Cell. Biol. 136: 215-227
Morin PJ, Vogelstein B and Kinzler KW (1996) Apoptosis and APC in colorectal tumorigenesis. Proc. Natl. Acad. Sci. USA. 93: 7950-7954

Munemitsu S, Souza B, Muller O, Albert I, Rubinfeld B and Polakis P (1994) The APC gene product associates with microtubules in vivo and promotes their assembly in vitro. Cancer Res. 54: 3676-3681

Munemitsu S, Albert I, Souza B, Rubinfeld B and Polakis P (1995) Regulation of intracellular $\beta$-catenin levels by the adenomatous polyposis coli (APC) tumorsuppressor protein. Proc. Natl. Acad. Sci. USA. 92: 3046-3050

Nicholson DW, Ali A, Thornberry NA, Vaillancourt JP, Ding CK, Gallant M, Gareau Y, Griffin PR, Labelle M, Lazebnik YA, Munday NA, Raju SM, Smulson ME, Yamin TT, Yu VL and Miller DK (1995) Identification and inhibition of the ICE-CED-3 protease necessary for mammalian apoptosis. Nature 376: 37-43

Ormerod MG, Sun X-M, Snowden RT, Davies R, Fearnhead H and Cohen GM (1993) Increased membrane permeability of apoptotic thymocytes - a flow cytometric study. Cytometry 14:595-602

Orth K, Chinnaiyan AM, Garg M, Froelich CJ and Dixit VM (1996) The ced-3/ICE-like protease Mch2 is activated during apoptosis cleaves the death substrate lamin A. J. Biol. Chem. 271: 16443-16446

Qin X-Q, Livingston DM, Kaelin, Jr WG and Adams PD (1994) Deregulated transcription factor E2F-1 expression leads to S-phase entry and p53-mediated apoptosis. Proc. Natl. Acad. Sci. USA 91: 10918-10922

Rubinfeld B, Souza B, Albert I, Muller O, Chamberlain H, Masiarz FR, Munemitsu S and Polakis $\mathrm{P}$ (1993) Association of the APC gene product with $\beta$-catenin. Science 262: 1731 - 1734

Rubinfeld B, Souza B, Albert I, Munemitsu S and Polakis P (1995) The APC protein and $\mathrm{E}$-cadherin form similar but independent complexes with $\alpha$-catenin, $\beta$ catenin, and plakoglobin. J. Biol. Chem. 270: 5549-5555

Smith KJ, Johnson KA, Bryan TM, Hill DE, Markowitz S, Willson JKV, Paraskeva C, Petersen GM, Hamilton SR, Vogelstein B and Kinzler KW (1993) The APC gene product in normal and tumor cells. Proc. Natl. Acad. Sci. USA. 90: 2846-2850

Smith KJ, Levy DB, Maupin P, Pollaed TD, Vogelstein B and Kinzler KW (1994) Wildtype but not mutant APC associates with the microtubule cytoskeleton. Cancer Res. 54: 3672-3675

SuL-K, Vogelstein B and KinzlerKW (1993) Association of the APC tumor suppresso protein with catenins. Science 262: $1734-1737$

Takahashi A, Alnemri ES, Lazebnik YA, Fernandes-Alnemri T, Litwack G, Moir RD, Goldman RD, Poirier GG, Kaufmann SH and Earnshaw WC (1996) Cleavage of lamin A by Mch2 $\alpha$ but not CPP32: Multiple interleukin $1 \beta$-converting enzymerelated proteases with distinct substrate recognition properties are active in apoptosis. Proc. Natl. Acad. Sci. 93: 8395-8400

Takahashi A and Earnshaw WC (1996) ICE-related proteases in apoptosis. Curr. Opin. Gen. Dev. 6: 50-55

Tan X, Martin SJ, Green DR and Wang JYJ (1997) Degradation of retinoblastoma protein in tumor necrosis factor- and CD95-induced cell death. J. Biol. Chem. 272: $9613-9616$

Tewari M, Quan LT, O'Rourke K, Desnoyers S, Zeng Z, Beidler DR, Poirier GG, Salvesen GS and Dixit VM (1995) Yama/CPP32 $\beta$, a mammalian homolog of CED-3 is a CrmA-inhibitable protease that cleaves the death substrate poly(ADP-ribose) polymerase. Cell 81: 801-809

Thornberry NA, Bull HG, Calaycay JR, Chapman KT, Howard AD, Kostura MJ, Miller DK, Molineaux SM, Weidener JR, Aunins J, Elliston KO, Ayala JM, Casano FJ, Chin J, Ding GJ-F, Egger LA, Gaffney EP, Limjuco G, Palyha OC, Raju SM, Rolando AM, Salley JP, Yamin T-T, Lee TD, Shively JE, MacCross M, Mumford RA, Schmidt JA and Tocci MJ (1992) A novel heterodimeric cysteine protease is required for interleukin-1 $\beta$ processing in monocytes. Nature (Lond.) 356: 768-774

Thornberry NA and Molineaux SM (1995) Interleukin-1 $\beta$-converting enzyme - a nove cysteine protease required for IL-1 $\beta$ production and implicated in programmed cell death. Protein Science 4: 3-13

Wu Xand Levine A (1994) p53 and E2F-1 cooperate to mediate apoptosis. Proc. Natl. Acad. Sci. USA. 91: 3602-3606

Wyllie AH, Morris RG, Smith AL and Dunlop D (1984) Chromatin cleavage in apoptosis: association with condensed chromatin morphology and dependence on macromolecular synthesis. J. Pathol. 142: 67-77

Yuan J, Shaham S, Ledoux S, Ellis HM and Horowitz HR (1993) The C. elegans cell death gene ced-3 encodes a protein similar to mammalian interleukin-1 $\beta$ converting enzyme. Cell 75: 641-652

Zhu H, Fearnhead HO and Cohen GM (1995) An ICE-like protease is a common mediator of apoptosis induced by diverse stimuli in human monocytic THP.1 cells. FEBS Lett. 374: 303-308 